\title{
MINDFULNESS AND WORK ENGAGEMENT AMONG GENERATION Y
}

\author{
MINDFULNESS DAN WORK ENGAGEMENT DI ANTARA GENERASI Y \\ By: \\ Endro Puspo Wiroko ${ }^{1}$ \\ Evanytha ${ }^{2}$
}

\section{Submited : \\ 3 April 2019 \\ Revision : \\ 12 April 2019}

\section{Accepted :}

29 Agustus 2019

\begin{abstract}
ABSTRAK
Salah satu konsep yang muncul dalam psikologi kesehatan kerja (occupational health psychology) saat ini adalah work engagement. Penelitian ini menyelidiki work engagement di antara generasi $\mathrm{Y}$ dan korelasinya dengan perhatian. Work engagement adalah positif, memuaskan, pekerjaan yang terkait dengan kondisi pikiran yang ditandai dengan semangat, dedikasi, dan penyerapan. Mindfulness adalah kesadaran saat sekarang dengan sikap mengamati dan tidak menghakimi. Ini adalah studi pertama yang menguji korelasi antara mindfulness dan work engagement di antara generasi Y, khususnya di Indonesia. Partisipan penelitian ini adalah 251 pria dan wanita generasi Y yang bekerja di beberapa kota di seluruh Indonesia. Mereka berusia 18 hingga 36 tahun dan memiliki latar belakang pendidikan yang bervariasi serta masa kerja. Data dikumpulkan dengan menggunakan dua skala, yaitu Utrecht Work Engagement Scale dan Mindful Attention Awareness Scale. Analisis regresi melaporkan bahwa mindfulness berkontribusi 2 persen untuk Work Engangement. Mindfulness ditemukan berhubungan positif dengan work engagement $(\mathrm{r}=.142)$. Implikasi teoretis dan praktis dibahas.
\end{abstract}

Kata kunci: generasi $Y$; mindfulness; work engagement

\begin{abstract}
One of the emerging concepts in occupational health psychology today is work engagement. The present study investigates work engagement among generation $\mathrm{Y}$ and its correlation to mindfulness. Work engagement is positive, fulfilling, work-related state of mind that is characterized by vigor, dedication, and absorption. Mindfulness is present moment awareness with an observing and nonjudging stance. This is the first study to examine the correlation between mindfulness and work engagement among generation Y, specifically in Indonesia. Participants of this study were 251 male and female generation $\mathrm{Y}$ working in some cities across Indonesia. They were 18 to 36 years old and they were varied in educational background as well as in job tenures. Data was gathered using two scales, namely Utrecht Work Engagement Scale and Mindful Attention Awareness Scale. Regression analysis reported that mindfulness contributes 2 percent to work engagement. Mindfulness is found to relate positively with work engagement $(\mathrm{r}=.142)$. Theoretical and practical implications are discussed. Keywords: generation $Y$; mindfulness; work engagement
\end{abstract}

\section{INTRODUCTION}

Work engagement has become one of popular topics in occupational health psychology (Bakker, Schaufeli, Leiter, \& Taris, 2008). Many researchers in occupational health psychology field is trying to discover more facts about antecedents and consequences of work

\footnotetext{
${ }^{1}$ Endro Puspo Wiroko, Faculty of Psychology Universitas Pancasila, Email : endro.puspowiroko@univpancasila.ac.id

${ }^{2}$ Evanytha, Faculty of Psychology Universitas Pancasila, Email : evaoktober@yahoo.com
} 
engagement. Engaged workers are healthy ones, both physically and psychologically (Bakker, 2011). Those who are engaged in their work were found to report low frequency of medical leave for about 2,68 days per year, whereas the disengaged workers showed higher frequency of medical leave for about 6,19 days per year (Krisbiyanto, 2013). Promoting engagement in the workplace may have more positive organizational effects than a more traditional disease prevention focus, since engagement is contagious and closely related to motivation and good performance (Torp et al, 2013). The concept of promoting work engagement is also align with the emerging values of positive psychology. As positive psychology tries to look at positive sides of an individual, so does work engagement.

Work engagement is one of the main factors that determine the success of a company (Hoole \& Bonnema, 2015). From the individual perspective, employees with high level of engagement tend to complete all work assigned (Schaufeli, Taris, Van Rhenen, 2008). Therefore, engaged employees would give benefit to the company since they could deliver good work performance (Christian, Garza, \& Slaughter, 2011). If employees were engaged at work, the company's productivity and goal could be achieved. In contrary, those who do not have sense of attachment to their job would display unfavorable performance and low productivity (Bates, 2004). The disengaged employees may become threat to the company since they could not contribute to company's goal achievement.

Despite the positive advantages of work engagement, Gallup's latest research on employee engagement showed an unfavorable outcome. Worldwide, there are only $13 \%$ employees who are engaged at work. Only $8 \%$ of Indonesian employees are engaged at work, $77 \%$ are not engaged, while $15 \%$ are actively disengaged (Crabtree, 2013). In this opportunity, the Researchers were interested to look further at a symptom of low work engagement among Generation Y in Indonesia.

Companies today are dominated by Generation $\mathrm{Y}$ and they are predicted to grow twice larger than Generation X. Some people mention Generation Y by using their popular name that is Millennial. Current organizations consist of different generations (Delcampo, Haggerty, Haney, \& Knippel, 2011), they are Baby Boomers (1946-1964), generation X (1965-1980), and generation Y (1981-2000). Anitha and Aruna (2016) mentioned that Millennials are a generation whose attitudes, expectations, and work values are significantly different from previous generations. These differences are caused by the growing globalization, foreign investment, employment, and digital technology (Liyanage \& Gamage, 2017).

Generation Y people are often known as information savvy, and they have broad knowledge and high multitasking skill (Tay, 2011). These characteristics were mentioned to be in contrary with the characteristics possesed by their previous generation. However, they are also well-known to be job hopper, a term given to those who easily move from one company to another within short tenure. Once they feel bored and there is a lack of challenge in their work, they tend to look for other jobs in different companies. (Ozcelik, 2015). Swiggard (2011) also mentioned that generation $\mathrm{Y}$ tend to move to other companies after one year tenure. This tendency is twice as big as those from generation $\mathrm{X}$. Generation $\mathrm{X}$ are assumed to stay longer than Generation $\mathrm{Y}$ in a company. The explanation above lead the Researchers to assume that work engagement among generation $\mathrm{Y}$ is low.

Based on JD-R (job demands-resources) model, work engagement could be predicted by job demands, job resources, and personal resources (Bakker, 2011). Job demands is the degree of work environment in giving stimulus, so that they need to be responded. Some aspects included in job resources are physical, social, and organizational environment, compensation, career opportunity, supervisor support, coworker support, and performance feedback. Meanwhile, aspects included in personal resources are self-efficacy, optimism, hope, and resilience. 
From those various aspects, the Researchers would like to focus on examining the personal resources. Personal resources are characteristics owned by each individual referring to positive self evaluation and also referring to individual's capacity to control his or her surrounding (Hobfoll, Johnson, Ennis \& Jackson, 2003). Possessing an adequate personal resource and deliver it to daily work would give positive impact to individuals. Some example of personal resources are self esteem, self efficacy, self control, and ability to control emotion (Albrecht, 2010). When used wisely, each of those personal resources could support employees in delivering expected performance. In this matter, the Researchers would like to propose a psychological characteristic related to controlling emotion, namely mindfulness.

Mindfulness is an ancient concept due to its roots lie in various lines of Buddhist thought going back over two millennia. Looking at its advantage to one's overall well-being, the concept of mindfulness has recently entered the scientific arena as a construct of interest. Mindfulness can be defined as "enhanced attention to and awareness of current experience or present reality" (Brown \& Ryan, 2003), resulting in perceptions of internal and external events without distortions (Brown \& Kasser, 2005). Being mindful does not only mean being in focus or high concentration, but also mean to give extra attention to what someone is doing. Mindfulness can play a crucial role in the work context of managers or teachers (Napoli, 2006). Mindful managers may deliver appropriate decision and mindful teachers may deliver subjects material well. In addition, mindfulness can be beneficial in settings where interpersonal contact is required in general. Mindful workers could still give attention to their tasks without leaving teamwork behind. An employee needs to have adequate self empowerment both cognitively and emotionally in order to be fully engaged at work (Yuan, Li, \& Tetrick, 2015). Mindfulness as one of personal resources could empower someone to show positive energy at work.

The Researchers utilizes the self determination theory to explain the relationship between mindfulness and work engagement. It explains that an open awareness may be beneficial in facilitating the choice of behaviors that are consistent with individual's needs, values, and interests (Deci \& Ryan, 1980). Work engagement has positive impact on good performance and people work to satisfy their needs, values, and interests. Engaged people are those who feel relatedness between themselves and their work. Mindfulness may facilitate the fulfillment of relatedness (Brown \& Ryan, 2003). Mindful workers would not feel detachment to their tasks. They would feel enjoyment and contentment even in stressful situation. Thus, awareness can make someone more likely to regulate behavior, in this case is achieving work target. The type of awareness offered by mindfulness is the one when someone can show full awareness with wide attentional breadth (Dane, 2011).

Research on the topic of mindfulness has its origin in the 1970's and shows beneficial impacts on clinical interventions, psychological outcomes, health, and well-being (Brown \& Ryan, 2003). Not only popular in clinical interventions, mindfulness now becoming one of variables to be explored in work setting. Regarding the workplace context, the investigation of mindfulness is getting more intense in recent years (Williams, Ciarrochi, \& Deane, 2010). However, research exploring the relationship among mindfulness and workplace variables is still underrepresented (Dane, 2011). Specifically, research is underdeveloped with regard to whether mindfulness influences how individuals perform their tasks at work. To the Researchers' knowledge, results on the relationship between mindfulness and positive workrelated concepts of well-being are still scarce. Based on those arguments, in alignment with the emerging positive psychology, the Researchers would like to focus on the association between mindfulness and work engagement.

Within Researchers' knowledge, published researches on work engagement among Millennials in Indonesia are still very few in number. The significance of this study lies in its theoretical and practical approach. The Researchers explored the relationship pattern of one 
variable that presumably influence the Millennials' work engagement. To date, this research is the first one in examining the relationship between mindfulness and work engagement. Looking at its practical approach, the Researchers argued that companies nowadays would get benefit from exploring factors that could affect the Millennials' engagement.

Based on the above argument, the objective of this research is to examine the correlation between mindfulness and work engagement. This research proposes hypothesis that mindfulness correlates positively to work engagement among generation Y.

\section{RESEARCH METHOD}

Research Variables

Variables in this research are mindfulness as independent variable and work engagement as dependent variable.

Research Participants

In this research, participants were workers born during the period of 1982-1999 (Twenge \& Campbell, 2008). They were males and females, working for private companies in some cities across Indonesia for minimum 6 months tenure. Focus on private companies was an attempt to gain more homogeneus data rather than spreading it to all types of company. Researchers did not have exact number of study population. Therefore questionnaires were distributed online by using purposive sampling. In order to encourage potential participants, shopping vouchers as reward token were granted to some lucky ones. Final eligible participants were 251 people.

\section{Data Collection Instruments}

Instruments used in this study were adaptation version of Utrecht Work Engagement Scale (UWES) and Mindful Attention Awareness Scale (MAAS). Participants were asked to response to the scales. Both measures used Likert scale with five different answer options ranging from almost never (1) to always (5).

UWES was originally designed by Schaufelli \& Bakker (2003). This tool consists of fourteen questions and measures three dimensions of work engagement: vigor, dedication, and absorption. Examples of items are: "At my work, I feel bursting with energy" for vigor dimension, "I am enthusiastic about my job" for dedication dimension, and "I feel happy when I am working intensely" for absorption dimension.

MAAS was originally developed by Brown \& Ryan (2003). This tool consists of fifteen questions. Examples of items are "I could be experiencing some emotion and not be conscious of it until some time later" and "I find myself preoccupied with the future or the past".

After conducting professional judgement to examine the scales' content, the Researchers used the Alpha-Cronbach formulation to count the reliability of the instrument on a pilot study. The final UWES has a reliability coefficient of $\alpha=.800$. Analysis of 14 items results in 11 reliable items. Meanwhile, the final MAAS has a reliability coefficient of $\alpha=.790$. Analysis of 15 items results in 11 reliable items.

Data Analysis Method

Data was analyzed using the technique of simple regression.

\section{RESULT AND DISCUSSION}

Based on demographic data in table 1, the sample of 251 Generation Y employees consists of $63 \%$ female and $37 \%$ male. Moreover, majority of respondents were staff (63\%), 
permanent (68\%), have worked for 1-3 years (46\%), hold Bachelor degree (76\%), and work in DKI (Special Province of) Jakarta (71\%).

Table 1.

Demographic Data

\begin{tabular}{lll}
\hline Variable & Category & Percentage \\
\hline Gender & Male & 37 \\
Job level & Female & 63 \\
& Staff & 63 \\
& Supervisor & 30 \\
Employment Status & Manager & 7 \\
& Permanent & 68 \\
Tenure & Contract & 32 \\
& < 1 year & 31 \\
Educational degree & 1-3 years & 46 \\
& 3-5 years & 19 \\
& >5 years & 4 \\
Work location & Diploma & 8 \\
& Bachelor & 76 \\
& Master & 16 \\
& DKI Jakarta & 71 \\
& Outside DKI Jakarta & 29 \\
\hline
\end{tabular}

Participants' score in mindfulness and work engagement can be seen in table 2. This table explains the distribution level of work engagement and mindfulness.

Table 2.

Participants' scores

\begin{tabular}{lllll}
\hline & Xmax & Xmin & Mean & SD \\
\hline Work engagement & 80 & 30 & 59.37 & 8.735 \\
Mindfulness & 55 & 25 & 40.07 & 7.194 \\
\hline
\end{tabular}

Table 3 presents the score categorization used in work engagement and mindfulness. These norms of categorization were established based on the assumption that scores of the subjects were in normal distribution. Level of work engagement among participants was mostly moderate $(66 \%)$ and level of mindfulness was mostly moderate $(58.6 \%)$ as well.

Table 3.

Score categorization of work engagement and mindfulness

\begin{tabular}{lllll}
\hline Category & Norm & Score & Total & Percentage \\
\hline High & $(\mu+1.0 \sigma) \leq X$ & $X \geq 68.105$ & 46 & 18 \\
Moderate & $(\mu-1.0 \sigma) \leq X<(\mu+1.0$ & $50.635<X<$ & 166 & 66 \\
& $\sigma)$ & 68.105 & & \\
Low & $X<(\mu-1.0 \sigma)$ & $X \leq 50.635$ & 39 & 16 \\
\hline Category & Norm & Score & Total & Percentage \\
\hline High & $(\mu+1.0 \sigma) \leq X$ & $X \geq 47.264$ & 55 & 21.9 \\
Moderate & $(\mu-1.0 \sigma) \leq X<(\mu+1.0$ & $32.876<X<$ & 147 & 58.6 \\
& $\sigma)$ & 47.264 & & \\
Low & $X<(\mu-1.0 \sigma)$ & $X \leq 32.876$ & 49 & 19.5 \\
\hline
\end{tabular}


After confirming that data is normal and linear, hypothesis testing is executed. Simple regression analysis shows that mindfulness correlates positively to work engagement. Hypothesis testing result shows correlation coefficient number of $r_{x y}=.142$ with significance $\mathrm{p}=.000(\mathrm{p}<.05)$. Positive mark in correlation coefficient shows that the higher one's mindfulness level then his or her work engagement could increase. Therefore, hypothesis is accepted. Determination coefficient score $\left(R^{2}\right)$ in this research is 0,020 so that effective contribution from mindfulness to work engagement is $2 \%$, while the rest $98 \%$ could be affected by other variables that are not measured in this research.

It is hypothesized that mindfulness would correlate positively to work engagement. Result shows that the hypothesis is accepted. The findings prove that mindfulness contribute positively to work engagement. Looking at the result, the Researchers would like to highlight some points to be discussed. First, although the correlation between two variables is weak, at least this research has proven that mindfulness correlates positively to work engagement. Behaving with awareness is defined as giving full attention to the present activity (Baer et al., 2006). People who are mindful when finishing their tasks would not be easily distracted by unfavorable stimulus, so they could focus on achieving their work target. When an employee has a high level of acting with awareness, he is able to identify and develop solutions to conflicts, therefore helping rise to the high energy at work (Dane, 2011). Mindful workers would tend to have clear mind so they could deliver variety of solution alternatives that could be useful to solve problems, whereas those who are not mindful tend to only perform limited solutions. This research offer new finding that mindfulness as personal resource also related to one's motivation in achieving work target.

As previously mentioned, mindfulness is still more popular in clinical interventions (Brown \& Ryan, 2003). If we look back at its roots, mindfulness is identical with intervention targeted to those with clinical symptoms. The most popular one is mindfulness therapy to reduce stress in general. However, some attempts have been made in organization setting to promote mindfulness as tool in promoting workplace well-being in recent years (Spence, G. B., 2017). To date, more companies are adopting the concept of mindfulness-based work stress reduction program. Not only to buffer work stress, mindfulness is also explored to investigate its relationship with work performance, team dynamics, and interpersonal relationship at work. Moreover, mindfulness is now becoming more popular among organizational psychologists who practice coaching because mindfulness has positive contributions to coaching efficacy from the point of view of the coach, the coachee, and the coaching relationship itself (Cavanagh $\&$ Spence, 2013). Result of this research may support the extensive exploration of mindfulness in workplace setting specifically by choosing work engagement variable.

Second, looking at the weak correlation score as well as small contribution, there could be some possibilities. If we look further at the items of both scales used in this research, we can comprehend that there is a different time perspective responded by participants. Items in work engagement evaluates one's attitude toward his or her past and present job, whereas items in mindfulness evaluates one's attitude toward his present behavior only. This argumentation could be supported by fact that mindfulness is talking about moment-by-moment awareness (Heads, 2017) and heightened present attention (Taylor, 2015). Mindfulness also has the person-focus on immediate experience to be in contrary with future-oriented worries or pastfocused rumination (Sarafino \& Smith, 2014). Work engagement specifically evaluate one's work attitude with broad time, whereas mindfulness specifically evaluate one's behavior with present time perspective.

Continuing above second point, The Researchers missed to review the characteristics of generation $\mathrm{Y}$ as participants. At the beginning of this research, The Researchers did not have 
adequate access to targeted literatures so The Researchers utilised any affordable sources that is still align with the objective of this research. Employees of generation $\mathrm{Y}$ are found to have strong interest to get promoted quickly, so they prefer to work in fast pace in order to achieve target fast (Ng, Schweitzer, \& Lyons, 2010). The Researchers assume that this characteristic make them show less awareness or attention to the environment. It is also possible that the variable mindfulness may not match to be examined among generation Y. Also, the Researchers assumed that there may be an intervening variable between mindfulness and work engagement.

Third, most participants are in moderate level of work engagement. This is contradictive with the researchers' previous assumption. Most of participants also have worked for one to three years, as opposed to less than a year. This information may also support the fact about moderate level of work engagement. This matter may be caused by participants' subjective response to work engagement scale. After conducting a deeper literature review, the Researchers found that Generation Y's work engagement in Indonesia is not as unfavorable as previously assumed. In one of private banks' headquarter in Jakarta, Azizah and Ratnaningsih (2018) found that generation Y's level of work engagement is mostly high. In their research among generation $\mathrm{Y}$ in national private, multinational private, and public sector, Forastero, Sjabadhyni, \& Mustika (2018) found that most of generation Y have worked for three to six years, as opposed to less than three years.

Two main limitations were encountered during the research process. First, the number of the sample used in this study is very small $(n=251)$ in contrast to the total generation $Y$ population in Indonesia. Type of companies are also homogeneous, namely private companies, while there are still so many generation $\mathrm{Y}$ working in state owned companies or working as public servants. These may lead to lesser accuracy in result generalization. Based on this research, this result can only be generalized among generation $\mathrm{Y}$ working in private companies. Second, cross-sectional nature of this study is potential to bias. Podsakoff et al (2003) suggests that longitudinal data may be gathered.

\section{CONCLUSION}

Based on the analysis, it can be concluded that mindfulness has positive correlation with work engagement among generation Y. The more mindful an individual, then he or she would be more engaged in work.

As a practical suggestion, companies may conduct mindfulness training to enhance their employees' work engagement especially generation Y working in private companies with specific condition. The training could be combined with another material or topic that is previously proven to have solid impact in increasing work engagement.

As for further research, there are some suggestions. First, it is understood that correlation between two variables is weak, so it is important to explore possible intervening (mediator) variables. This research gives opportunity for next researchers to examine the underlying mechanism between mindfulness and work engagement. Second, bigger samples may also lead to better population representativeness. Next researcher may try to distribute the questionnaire in form of hardcopy or online to targeted participants with longer duration. Characteristics of participants also have to be explored such as demographic data. Third, deeper literature reviews are needed before conducting any research on mindfulness and work engagement. Until today, researchers cannot find a trustworthy data regarding the level of work engagement among generation $\mathrm{Y}$ in Indonesia across occupations and types of company. Therefore, claim on certain level of work engagement in Indonesia must be carefully made. Literatures on mindfulness may also be explored further to reach better comprehension of its concept. Last, in gathering data, if possible, a longitudinal attempt as well as multi rating 
method could be useful. This last suggestion give clue to next researcher to perform much better preparation in data gathering.

\section{ACKNOWLEDGEMENT}

The Researchers would like to thank certain parties or people who have supported this research. First, Faculty of Psychology Universitas Pancasila for the internal grant. Second, students (M. Ilham Anugrah and Kukuh Deswari P.) for assisting the proposal process. Third, Mr. Obay Jambari, M.Pd for proofreading this article. Finally, committee of International Conference on Social Determinants of Health for the opportunity to present Researchers' idea.

\section{REFERENCES}

Albrecht, S. L. (2010). Research and practice: Handbook of employee engagement perspective issues. Cheltenham: MGP Books Group.

Anitha, J., \& Aruna, M. (2016). Enablers of employee engagement of gen Y at the workplace with reference to automobile sector. Amity Journal of Training and Development, 1(1), 93-108. Retrieved from http://www.amity.edu/UserFiles/admaa/248paper7.pdf

Azizah, R., \& Ratnaningsih, I. Z. (2018). Hubungan antara job crafting dengan keterikatan kerja pada karyawan generasi Y di kantor pusat PT Bank Bukopin. Jurnal Empati, 7(3), 167-173.

Baer, R. A.., Smith, G. T., Lykins, E., Button, D., Krietemeyer, J., \& Toney, L. (2006). Using self-report assessment methods to explore facets of mindfulness. Assessment, 13(1), 2745.

Bakker, A. B. (2011). An evidence-based model of work engagement. Current Directions in Psychological Science, 20(4), 265-269.

Bakker, A. B., Schaufeli, W. B., Leiter, M. P. \& Taris, T. W. (2008). Work engagement: an emerging concept in occupational health psychology. Work \& Stress, 22(3), 187-200. https://doi.org/10.1080/02678370802393649

Bates, S. (2004). Getting engaged. HR Magazine, 44-51.

Brown, K. W., \& Kasser, T. (2005). Are psychological and ecological well-being compatible? The role of values, mindfulness, and lifestyle. Social Indicators Research, 74, 349-368.

Brown, K. W., \& Ryan, R. M. (2003). The benefits of being present: Mindfulness and its role in psychological well being. Journal of Personality and Social Psychology, 84(4), 822848. https//doi.org/10.1037/0022-3514.84.4.822

Cavanagh, M. J. \& Spence, G. B. (2013). Mindfulness in coaching: Philosophy, psychology or just a useful skill? In J. Passmore, D. B. Peterson, \& T. Freire (Eds.), The Wiley Blackwell Handbook of The Psychology of Coaching and Mentoring (pp. 112-134). West Sussex: John Wiley \& Sons Ltd.

Christian, M. S., Garza, A. S., \& Slaughter, J. E. (2011). Work engagement: A quantitative review and test of its relations with task and contextual performance. Personnel Psychology, 64(1), 89-136. https://doi.org/10.1111/j.1744-6570.2010.01203.x

Crabtree, S. (2013). Worldwide 13\% employees are engaged at work. Retrieved from http://www.gallup.com/poll/165269/worldwide-employees-engaged-work.aspx

Dane, E. (2011). Paying attention to mindfulness and its effects on task performance in the workplace. Journal of Management, 37(11), 997-1018. https://doi.org/ $10.1177 / 0149206310367948$

Deci, E. L., \& Ryan, R. M. (1980). Self-determination theory: When mind mediates behavior. The Journal of Mind and Behavior, 1, 33-43. 
Delcampo, R. G., Haggerty, L. A, Haney, M. J., \& Knippel, L. A. (2011). Managing the multigenerational workforce: From the GI generation to the millennials. Burlington: Gower Publishing Company.

Forastero, A., Sjabadhyni, B., \& Mustika, M. D. (2018). What millennials want: How to optimize their work. Psikohumaniora, 3(1), 1-16.

Heads, G. (2017). Discovering authenticity through mindfulness coaching. West Sussex: John Wiley \& Sons Ltd.

Hobfoll, S. E., Johnson, R. J., Ennis, N., \& Jackson, A. P. (2003). Resource loss, resource gain, and emotional outcomes among inner city women. Journal of Personality and Social Psychology, 84(3), 632-643.

Hoole, C., \& Bonnema, J. (2015). Work engagement and meaningful work across generational cohorts. SA Journal of Human Resource Management, 13(1), 1-11. https//doi.org/10.4102/sajhrm.v13i1.681

Krisbiyanto, N. (2013). Perjalanan mencari makna engagement bagi organisasi. Human Capital, 290, 112-116.

Liyanage, H. M., \& Gamage, P. (2017). Factors influencing the employee engagement of generation Y employees. In Proceedings of APIIT Business \& Technology Conference. Colombo.

Napoli, M. (2004). Mindfulness training for teachers: A pilot program. Complementary HealthPractice Review, 9(1), 31-42.

Ng, E. S. W., Schweitzer, L., \& Lyons, S. T. (2010). New generation, great expectations: A field study of the millennial generation. Journal of Business and Psychology, 25(2), 281292. http://dx.doi.org/10.1007/s10869-010-9159-4

Ozcelik, G. (2015) Engagement and retention of the millennial generation in the workplace through internal branding. International Journal of Business and Management, 10(3). https//doi.org/10.5539/ijbm.v10n3p99

Podsakoff, P. M., MacKenzie, S. B., Lee, J. Y., \& Podsakoff, N. P. (2003). Common method biases in behavioral research: A critical review of the litearure and recommended remedies. Journal of Applied Psychology, 88(5), 879-903. https//doi.org/10.1037/00219010.88.5.879

Sarafino, E. P. \& Smith, T. W. (2014). Health psychology biopsychosocial interactions 8th ed. New Jersey: John Wiley \& Sons, Inc.

Schaufeli,W. B., \& Bakker, A. B. (2003). UWES Utrecht Work Engagement Scale: Test Manual. Unpublished manuscript. Department of Psychology, Utrecht University, Utrecht, The Netherlands. Retrieved from http://www.schaufeli.com

Schaufeli, W. B., Taris, T. W., \& Van Rhenen, W. (2008). Workaholism, burnout, and work engagement: Three of a kind or three different kinds of employee well-being? Applied Psychology, 57(2), 173-203. https://doi.org/10.1111/j.1464-0597.2007.00285.x

Spence, G. B. (2017). Mindfulness at work. In L. G. Oades., M. F. Steger., A. D. Fave, \& J. Passmore (Eds.), The Wiley Blackwell Handbook of The Psychology of Positivity and Strengths-Based Approaches at Work (pp. 110-131). West Sussex: John Wiley \& Sons Ltd.

Swiggard, S. (2011). Generations and employee commitment: An exploration of the impact of changes in technology, home and family structure, and employer-employee relationship. Unpublished Dissertation. Capella University.

Tay, A. (2011). Managing generational diversity at the workplace: Expectations and perceptions of different generations of employees. African Journal of Business Management, 5(2), 249-255. https://doi.org/10.5897/AJBM10.335

Taylor, S. E. (2015). Health psychology 9th ed. New York: McGraw-Hill. 
ENDRO PUSPO WIROKO \& EVANYTHA, Mindfulness And Work Engagement Among Generation

Torp, S., Grimsmo, A., Hagen, S., Duran, A., \& Gudbergsson, S. B. (2013). Work engagement: a practical measure for workplace health promotion? Health Promotion International, 28(3), 387-396. https://doi.org/10.1093/heapro/das022

Twenge, J. M., \& Campbell, S. M. (2008). Generational differences in psychological traits and their impact on the workplace. Journal of Managerial Psychology, 23(8), 862-877. https://doi.org/10.1108/02683940810904367.

Williams, V., Ciarrochi, J., \& Deane, F. P. (2010). On being mindful, emotionally aware, and more resilient: Longitudinal pilot study of police recruits. Australian Psychologist, 45(4), 274-282.

Yuan, Z., Li., Y., \& Tetrick, L. (2015). Job hindrances, job resources, and safety performance: The mediating role of job engagement. Applied Ergonomics, 51, 163-171. https://doi.org/10.1016/j.apergo.2015.04.021. 